\title{
Corruption In Sports Environment ${ }^{1}$
}

\author{
Bronislava Coufalová, Jan Pinkava ${ }^{2}$
}

\section{Faculty of Law, Palacký University Olomouc, Czech Republic email: bronislava.coufalova@upol.cz, jan.pinkava@upol.cz}

COUFALOVÁ, B. - PINKAVA, J. Corruption in Sports Environment. International and Comparative Law Review, 2013, Vol. 13., No. 2, pp. 97-110. DOI: 10.1515/iclr-2016-0073.

\begin{abstract}
In sports environment there is a whole range of different types of wrongful conduct sanctioned not only by disciplinary bodies using specific rules accepted by the executive authorities of sports organizations but also more serious cases that have to be judged in accordance with criminal law. There has been a long debate whether criminal law should intervene into the area of sport, i.e. whether sport and its environment is in itself such an autonomous system that it could deal with all the matters of criminal nature on its own. The area of sport environment involves a whole range of illegal acts, ranging from criminal liability of sportsmen responsible for injuries inflicted upon others in the area of sport, the issues of hooliganism in sporting events, breach of the public peace as far as the issue of match-fixing including the crimes of bribery and illegal betting. Generally speaking, we are of the opinion that there is no good reason why the criminal law should not be allowed to intervene into the area of sport in certain cases. The basic argument to be used is the fact that every social activity must be carried out in accordance with the legal order of the country, the area of sport being no exception. The area of sport or to be more precise the specific types of sports activities are regulated by special internal and statutory rules introducing certain sanctioning mechanisms in the form of disciplinary rules which can be enforced by different disciplinary bodies.
\end{abstract}

Keywords: sports environment, corruption, match-fixing, illegal betting, disciplinary rules, criminal liability of sportsmen

\section{Introduction}

In sports environment there is a whole range of different types of wrongful conduct sanctioned not only by disciplinary bodies using specific rules accepted by the executive authorities of sports organizations but also more serious cases that have to be judged in accordance with criminal law. There has been a long debate ${ }^{3}$ whether criminal law should intervene into the area of sport, i.e. whether sport and its environment is in itself such an autonomous system that

1 This article was elaborated under the project IGA - SPP 917100238/31 - Criminal liability in sports environment.

2 Department of Criminal Law, Faculty of Law, Palacký University in Olomouc, Czech Republic.

3 More about this issue for example Králík, M.: Komparativní pohled soudobé právní doktríny soudní praxe na právní odpovědnost sportovců za sportovní úrazy. Bulletin advokacie 2006, no. 9, p. 25. 
it could deal with all the matters of criminal nature on its own. The area of sport environment involves a whole range of illegal acts, ranging from criminal liability of sportsmen responsible for injuries inflicted upon others in the area of sport, the issues of hooliganism in sporting events, breach of the public peace as far as the issue of match-fixing including the crimes of bribery and illegal betting.

Generally speaking, we are of the opinion that there is no good reason why the criminal law should not be allowed to intervene into the area of sport in certain cases. The basic argument to be used is the fact that every social activity must be carried out in accordance with the legal order of the country, the area of sport being no exception. The area of sport or to be more precise the specific types of sports activities are regulated by special internal and statutory rules introducing certain sanctioning mechanisms in the form of disciplinary rules which can be enforced by different disciplinary bodies. However, there are certain ways of conduct which cannot only be sanctioned under the disciplinary rules as they also require sanctions applied under the system of legal norms. In cases of the application of criminal sanctioning for injuries inflicted in the course of sports activities it is more difficult to impose such a sanction (but, this issue is not covered in this article). However, in cases of fraudulent behavior, bribery and corruption in the area of sport there is no reason why the criminal law rules should not be applied. This is the type of conduct showing the same signs as and having the nature of property crime. In some of these cases the application of disciplinary rules and sanctions would be insufficient, thus the criminal law sanctions will have to be applied. It is essential that bribery in all its forms as the crime that can be found in all society should be sanctioned not only for the sake of the repression itself, but also as a prevention and deterrent of further crime of this type. This is the main reason why the criminal law will be applied in these cases. Such cases of corruption in sports environment cannot be separated from other cases that can be found in other social activities saying that the area of sports environment is so autonomous that it can sanction such conduct on its own.

On the contrary, it can be stated that in order to effectively sanction these cases of corruption it is essential that a certain type of mutual cooperation between the disciplinary bodies and specific state authorities should be applied. These authorities regard this type of corruption as a specific type of crime, or in other words crime committed in a specific type of environment. This type of effective mutual cooperation will definitely result in a faster and thorough investigation of all circumstances and more effective sanction imposed for the crime committed.

It is the issue of corruption, bribery and illegal betting mentioned above that will be dealt with in the following paragraphs. Criminal law regards such conduct as the crime against the order in public affairs combined with property crime (including bribery, fraudulent behavior etc.). The expression match-fixing (spot-fixing or sport manipulation) can be understood as illegal (or non-ethical) 
manipulating or an attempted manipulating of a match while in progress (or the result of a match) with the intent to gain certain financial or other benefit that can be acquired through persons involved in the sporting activity.

The issue of corruption, illegal betting and bribery itself includes apart from other things a whole range of typified conduct which can be, under certain circumstances, sanctioned under the rules of criminal law. For the purposes of this paper we have split them into two groups.

Bribing private persons who perform or in a way participate in sporting activities constitutes the first group of such wrongful conduct. It includes apart from other things bribing referees, particular sportsmen (no matter whether it is in individual or collective types of sporting activity). Then it also includes bribing particular sports clubs, teams or the representatives of such teams. From this perspective we can also talk not only about the criminal liability of private persons but also about liability of legal persons. These cases are not merely hypothetical cases based on an imaginary theoretical events, but they are real cases currently being solved in our legal environment. Some of them will be analyzed in the following text. The most frequent type of crime currently debated will probably be the illegal sport manipulation through bribing referees, arbiters etc.

On the other hand cases of illegal betting where the sportsman or another person intentionally manipulates the match result in order to gain some financial or other benefit for himself or for somebody else falls within the second group. It should be noted that in practice both groups briefly outlined above mingle with each other and mutually interact, which can also be seen in the specific cases analyzed in the following text.

The question of organized crime connected to the wrongful conduct in sports environment that has been touched upon above could also be a part of the issues discussed in this paper. It is especially the most serious high-profile corruption cases where it can be seen that the wrongful conduct was not a mere excess but a sophisticated system of illegal manipulation with the results of certain sporting activities. The area of organized crime is such a serious issue that it requires sanctions imposed under the criminal law (the sanctioning according to the disciplinary rules only being highly insufficient in these cases). That is why we talk about the criminal liability of the offenders involved in this type of wrongful conduct. Prosecuting this type of crime by the authorities active in the criminal prosecution is also very important as these criminal organizations frequently do not only deal with corruption and illegal betting but they might also be involved in a more serious criminal activity such as e.g. drug dealing or human trafficking. That is why the investigation and subsequent prosecution of the wrongful conduct mentioned above may lead to revelation of a more serious criminal activity. 


\section{Corruption}

Corruption is a social-wide phenomenon penetrating into a whole range of different social activities to a larger or smaller extent. One of the social activities also affected by corruption is the area of sport. Cases of corruptive behavior can not only be found in public sector, but also in private sector, which is among others the area of sport activities. Corruption is a type of social wrongful conduct characteristic by a high degree of latency. It is only a small amount of such a conduct that will be revealed and sanctioned under disciplinary and criminal law rules while the substantial part of such a conduct remains undetected.

The evidence proceeding is another problematic aspect in the process of detecting such a criminal activity. This can also be seen in the cases analyzed in this article. There is a whole number of cases of suspicious behavior (such as e.g. bribery, frauds etc.) large number of which never ends in conviction as a result of lack of evidence or the inability to prove fault and other statutory elements of the crime. It should be noted that this is not a new phenomenon as its origins can be traced back in the history. However, this type of conduct is on the increase and it has become more visible in the last few decades as a result of the process of commercionalization. The phenomenon also relates to the recent conception of sport. Today professional sport can be regarded as a form of a wage earning activity which can be accompanied by a number of negative aspects.

Those involved in the sporting activities are sometimes under such a strong pressure to produce maximal economic results that they will resort to extreme solutions acting in violation of both, the disciplinary rules and even the legal order. In order to sanction less serious cases of wrongful conduct it will be enough to apply the disciplinary rules. The more serious cases will require sanctions imposed under the civil law and extreme cases of such a conduct will be sanctioned under the criminal law. In this context it should be noted that the breach of disciplinary rules does not necessarily mean a violation of legal order whereas the violation of legal rules should automatically equal to the breach of disciplinary rules which should be in harmony with the legal order.

As it has been mentioned above there is a whole range of different forms of corruption in the sports environment such as bribing referees, players, club officials, clubs, teams or the representatives of the teams etc. Bribing persons participating in sporting activities is a negative phenomenon and it can be said that this type of conduct is on the increase. Such bribery can be recently found in different types of sporting activities, both individual and collective. Bribing referees will probably be the most frequent type of such a corruptive behavior today. It is good to know that sport is a rather wide social activity, including a whole range of different sectors and sporting activities. That is why referees and arbiters have such a strong position as they can relatively easily manipulate the results of these activities to a lesser or bigger extent. In case of individual sports 
the position of these referees and arbiters is rather limited as their role is often considered as a supervisory or controlling one. However, the situation seems to be more problematic when it comes to collective sports where these persons have extensive rights and thus they can significantly manipulate the progression of such a sporting activity.

\section{Illegal betting}

These are the cases which include wrongful conduct consisting in illegal and intentional manipulation of a game progress on the part of the sportsman or other persons participating in the sporting activity with the intent to gain certain benefits, financial benefits etc. These are the cases of aimed manipulation of the sporting activities results which can mostly be found in the area of illegal betting itself.

The obvious danger of such a wrongful conduct can be found in individual sporting activities where the result depends upon the specific sportsman. In case of collective sports the manipulation with the sports results can be more difficult, however, it is not impossible. In order to illustrate the point we can choose a real case of a tennis match Davydenko - Arguello where Davydenko at that time the $4^{\text {th }}$ player of the ATP Chart decided to untimely withdraw from the match against Arguello - a tennis player who occupied the $87^{\text {th }}$ position in the ATP Chart at that time. The official reason for the withdrawal from the match was injury. This conduct was later analyzed and investigated by the ATP. The fact that someone bet 7 million pounds on the victory of the weaker player was the reason for such an investigation. The sum of money betted on the victory of the weaker player increased in the course of the match even though Davydenko won the first set. ${ }^{4}$ In the end Davydenko was acquitted and cleared of all charges even though it was stated that a certain amount of illegal manipulation had occurred in this case. ${ }^{5}$

It was also the scandal of an Austrian tennis player Daniel Koellerer which can be regarded as a high-profile case and to some extent also a landmark case in this area. Daniel Koellerer who was accused of a illegal manipulation of tennis matches in 2009-2010. A disciplinary authority sanctioned him by a life ban on the professional activity and a fine in the amount of US $\$ 100000 .^{6}$

Among those sanctioned by the life ban on the professional activity because of match-fixing and illegal manipulation with the results of tennis matches were

4 It was the betting office Betfair which drew the attention of the ATP saying that this bet was suspicious. This betting office has had an agreement with the ATP since 2003 to draw the ATP's attention upon suspicious betting in connection with tennis.

5 Inquiry Into Betting Clears Davydenko. In: [online]. [cit. 2013-11-06]. Available on: http:// www.nytimes.com/2008/09/13/sports/tennis/13tennis.html?_r=0.

6 Daniel Koellerer banned for life for match-fixing. In: [online]. [cit. 2013-11-06]. Available on: http://www.bbc.co.uk/sport/0/tennis/13608639. 
the Serbian tennis player David Savič ${ }^{7}$ and a Russian tennis player Sergej Krotiouk. $^{8}$

Those three mentioned above were the first tennis players to be sanctioned by this type of a strict penalty by the disciplinary authorities.

Another case that can be used as an example of match-fixing or illegal manipulation with match results in individual sports is the scandal involving Sumo Matches in Japan in 2011. This affair surfaced as a result of the investigation of a case of bribery in baseball where some Sumo wrestlers were also involved. As a result of analyses of phone calls and text messages it was proved that the results of some Sumo matches were also manipulated and fixed. During this scandal 13 professional Sumo wrestlers were accused including the main sponsor of these matches Tokitsukaze who later admitted to the wrongful conduct. In total 65 people were accused of this type of wrongful conduct. In the course of investigation it surfaced that it was JAKUZA, the infamous Japanese criminal organization which also participated in the manipulation with the results. As a result of this scandal the main tournament was cancelled. This was the first time this had happened from 1946. Those who participated in this conduct were not prosecuted in the end. ${ }^{9}$

However, it can be said that the number of such cases which have been detected recently is on the increase. Most of them are sanctioned mildly, i.e. on the disciplinary level. However, in order to detect this type of wrongful behavior it is essential that the betting offices should cooperate with the sports authorities and subsequently with the bodies in charge of criminal proceedings.

On the other hand in case of collective sports there is a danger of intentional match-fixing and manipulation with results on the part of referees in order to get some benefits through illegal betting. This will be demonstrated in the following text by analysis of a whole range of other cases which were solved in the Czech Republic as well as abroad. With team sports it is more difficult to manipulate the progress and result of the match by just one player or a member of a team. First, such a person merely represents a link in the whole team and thus his or her effort to manipulate the result does not necessarily have to be successful. Next, such players are much more under the surveillance of the other players their behavior being just one of the factors affecting the progress and the result of

7 Tennis player David Savic fails to have life-time ban for match-fixing overturned. [online]. [cit. 2013-11-06]. Available on: http://www.independent.co.uk/sport/tennis/tennis-playerdavid-savic-fails-to-have-lifetime-ban-for-matchfixing-overturned-8112851.html.

8 Russian Tennis Player Krotiouk Gets Life Ban for Match-Fixing. [online]. 2013 [cit. 201311-06]. Available on: http://www.bloomberg.com/news/2013-06-06/russian-tennis-player-krotiouk-gets-life-ban-for-match-fixing.html.

9 Japan: A final takedown for sumo wrestling?. [online]. 2011 [cit. 2013-11-09]. Available on: http://www.globalpost.com/dispatch/japan/110206/sumo-wrestling-scandal-matchfixing. 
a game or a match. Sometimes the whole team of players can be bribed and thus the result of the match is manipulated. This can be regarded as a very specific form of match-fixing.

Among team sports it is football that should be mentioned first in connection with illegal betting and corruption as it is the game where a whole number of corruptive behavior cases have recently been detected. Many European leagues including the Czech ones have been involved in these cases of corruptive behavior. It is good to say that this conduct has not only been limited to the top leagues but can also be found in lower level competitions (including youth competitions). The most frequent type of corruption in football is bribing the referees or individual players. However, bribing the referees is more frequent.

There is a whole range of different motives for corruption in the sports environment. These motives are closely connected with illegal betting. In these cases the reason for manipulation with the progress of a sporting activity or the results of sporting activities is financial gain. These are especially cases of betting on games or matches that have been fixed or manipulated. Other reasons for bribery of this kind can also be so called "sports reasons". In these cases the financial gain comes as the secondary reason. These are the cases when a sports team wants to go up to the upper level of the competition or does not wish to decline to the lower one. In such cases the manipulation with the progress of a match or the result of such a match occurs frequently. With individual sports the reason for such a manipulation can simply be the desire to get a certain sports award (such as e.g. Olympic medals, medals awarded at other types of sporting events such as World Championships or European Championships and other top sporting events or other types of awards that can be obtained in individual sports).

\section{Other specific forms of corruption in sports environment}

Apart from the most frequent forms of corruption mentioned above connected with the manipulation of sports results there are also other nontraditional forms of corruptive behavior in sport.

These are the cases when officials who are at the same time members of different sports committees or, generally speaking, who are members of executive or authoritative bodies have been bribed or manipulated. These members can affect the decision-making process and decide where some of the top sporting events (such as e.g. Olympic Games, World Championships, European Championships etc., i.e. the most important sporting events) will take place. It is relatively common to try and affect the venue of these top sporting events or better to say certain amount of lobbing is quite common in these cases.

However, it is a matter of question to what extent the amount of such influence is admissible or not. There is a good example of such a conduct which can be used to illustrate this point. It is the case of the Winter Olympic Games in Salt 
Lake City in 2002 when some members of the International Olympic Committee kept receiving certain benefits from the organizers of the Salt Lake City with the intention to get the approval to hold the Olympic Games in Salt Lake City. ${ }^{10}$ Nobody was prosecuted in this case, however, the authority in charge of the investigation of this conduct stated that this behavior could be regarded as a very serious breach of the rules. The suspicious behavior connected with the Summer Olympic Games in Sydney in 2000 was also the subject of investigation. Some members of the Olympic Committee were allegedly bribed, however, in this case it was concluded that the amount of manipulation was within the limits and did not constitute bribery or corruption. ${ }^{11}$ As we can see a certain amount of lobbing in this decision-making process is quite common. However, it should always stay within the limits. If it is clear that a bribery or a corruption has occurred then the individuals responsible for such behavior should be prosecuted.

There is a whole number of motives why bribery occurs in connection with the organization of the top sporting events. First, it is very convenient for the organizing countries or cities from the economic point of view as it can bring many economic benefits to the specific country or city. ${ }^{12}$ The second motive, which is definitely also very important is the fact that certain destinations can become more attractive as a result of these top events (it is worth saying that some top sporting events such as e.g. the World Championship in football held in South Africa in 2010, or Winter/Summer Olympic Games held in China etc. were highly unprofitable and loss-making from the economic viewpoint, however, these events were still very important for the specific countries).

Another reason why it is so beneficial for the organizing country or city can be represented by the fact that the top sporting event can create new employment positions, draw the attention of foreign or domestic investors, and attract sponsors etc. However, in some cases it has to be concluded that the sporting event was significantly loss-making and unprofitable ${ }^{13}$ and thus it has failed to fulfill the expectations of the organizers.

10 OLYMPICS; Leaders of Salt Lake Olympic Bid Are Indicted in Bribery Scandal. LONGMAN, Jere. [online]. 2000 [cit. 2013-11-30]. Dostupné z: http://www.nytimes. com/2000/07/21/sports/olympics-leaders-of-salt-lake-olympic-bid-are-indicted-in-bribery-scandal.html.

11 World: Asia-Pacific. [online]. 1999 [cit. 2013-11-08]. Dostupné z: http://news.bbc.co.uk/2/ hi/asia-pacific/296910.stm.

12 Kdo na olympiádě vydělal? Projděte si přehled pořádajících měst. In: [online]. [cit. 201311-08]. Available on: http://aktualne.centrum.cz/ekonomika/grafika/2012/07/22/prehledna-kolik-vyslo-poslednich-devet-letnich-ol/\#10.

13 How the 2004 Olympics Triggered Greece's Decline. [online]. [cit. 2013-11-08]. Available on: http://www.businessweek.com/articles/2012-08-02/how-the-2004-olympics-triggered-greeces-decline. 
In other cases manipulation occurs when the rights to televise some important sporting events or activities have been awarded not in accordance with the rules and thus favoring the events or games of the greatest importance.

In other cases the corruptive and wrongful conduct can be connected with manipulation with the occupying of positions in statutory, executive and disciplinary bodies of different sports organizations. Other cases can be connected with the issues of transferring of players, drafting of players to other leagues, manipulation occurring when passing professional tests or examinations (such as e.g. qualification tests aimed for referees). The corruptive behavior can also be connected with affecting the timetables and schedules of matches for the following year or the play-off part of a league etc. All these types of wrongful behavior will, however, not result in a criminal prosecution as the sanctions imposed in these cases will be of disciplinary character only. However, in all such cases the circumstances of each case will be carefully considered.

\section{Imposing Criminal Sanctions under the Czech Criminal Law - Possi- bilities}

Unlike some European countries (such as e.g. Italy, Malta or Portugal) which have special legislation regulating the criminal sanctions that can be imposed for a corruptive behavior in the sports environment the Czech Republic does not have a special legislation regulating this area. A whole number of sport sectors have adopted some disciplinary rules regulating the sanctions imposed for wrongful conduct. However, the application of such disciplinary sanctions is not sufficient especially in the most serious cases. The absence of a special legislation regulating the possibilities to impose criminal sanctions will not, however, prevent such sanctions from being imposed under the Czech legal order. The key legislation regulating this area will thus be represented by the Act N. 40/2009 Coll., of the Criminal Code, as amended. The Criminal Code does not specifically contain the provisions regulating the area of sanctions of illegal and wrongful conduct in sports environment, however, it does contain the provisions regulating the possibility to impose sanctions for frauds, corruption, bribery etc., which will also be applicable in the area of sports environment.

The basis of legal regulation of corruption in sports environment is the chapter number 10 of specific part of the Czech Criminal Code. There are several bodies of a crime which could be used to sanction corruption in this specific area of civic society:

$\$ 331$ - Bribe - Taking

$\$ 332$ - Bribe - Giving

$\$ 333$ - Indirect Bribery

$\$ 331$ : Whoever of one's own accord or through another for oneself or for another person in connection with a matter of public interest accepts or takes a promise 
of a bribe or whoever of one's own accord or through another in connection with a business of ones own or another for oneself or for another person accepts or takes a promise of a shall be sentenced to imprisonment for a term up to four years or a prohibition of activity.

Whoever under the conditions above requires a bribe shall be sentenced to imprisonment for a term from six months up to five years.

$\$ 332$ : Whoever other or for another gives, offers or promises a bribe person in connection with a matter of public interest or whoever other or for another in connection with a business of ones own or another gives, offers or promises a bribe shall be sentenced to imprisonment for a term up to two years or pecuniary penalty.

$\$ 333$ : Whoever asks for or accepts a bribe to use his influence or through another to affect the exercise of a public officials powers or for having done so shall be sentenced to imprisonment for a term up to three years.

Whoever gives, offers or promises a bribe on the grounds under sub-provision above shall be sentenced to imprisonment for a term up to two years.

Another body of a crime which could be used to sanction corruption is the provision number 209 - criminal offence of fraud (it is contained in the chapter five of special part of the Czech Criminal Code - crimes against property):

$\$ 209$ : Whoever enriches himself or another by misleading another person or by taking advantage of another personś mistake or by withholding substantial facts and thereby causing damage to another persons property which is not negligible shall be sentenced to imprisonment for a term up to two years or prohibition of activity or forfeiture of a certain thing or another property value.

In connection with the issues of organised crime the term organised criminal group could be used when we are speaking about sanctioning of corruption in sports environment. This term is contained in provision number 129 of the Czech Criminal Code and the definition is:

Organised criminal group shall mean a group of several persons, when such group has its own internal organisational structure with a division of roles (among individual persons) and their activities are aimed at attaining a profit by a systematic involvement in deliberate criminal activity.

The organised criminal group is closely connected with body of a crime under provision number 361 of the Czech Crimnal Code - criminal offence Participating in organised criminal group. Under this provision shall be sentenced to imprisonment from two years up to ten years or forfeiture of property whoever establishes organised criminal group or whoever participates or supports organised criminal group.

On the other hand the Czech Criminal Procedure Code (Act N. 141/1961 Coll.) has also many institutes which could be used in fighting with organised 
crime in sports environment. If it is assumed many participanst of these illegal activities is possible to use specific institute of so called King's/Queen's evidence, also called cooperating accused. ${ }^{14}$ This is no new institute as far as European countries are concerned and it has been in use in many European countries (such as e.g. Poland, Italy, France etc.). It could be one of the possible tools that could contribute to hastening and facilitating the activity of investigative, prosecuting and adjudicating bodies in connection with organized crime detection and sanctioning.

Under the provision $\$ 178$ a of the criminal code the accused is not granted immunity from prosecution i.e. they can be prosecuted, however, it is possible to lower the sentence or acquit the accused in case all the legal conditions have been met. $^{15}$

\section{Imposing Criminal Sanctions under some Foreign Legal Regulations}

As it has been mentioned above the Czech law does not contain any specific legislation regulating the issues of criminal liability in the area of sport, supplementing the Criminal Code. There are not any specific sport crimes covered in the Czech Criminal Code, however, the sanctions available for the wrongful conduct in sport can be based on general provisions regulating fraud, corruption, bribery etc. Many European countries are in the same situation as the Czech Republic. However, there are also some exceptions. Italy, Malta, and Portugal have adopted special legislation the aim of which is the sanctioning of wrongful and fraudulent conduct in sport. Bulgaria and Spain have supplemented the existing criminal legislation with specific crimes covering the area of matchfixing and illegal manipulation in the area of sport. Other countries (Cyprus, Poland and Greece) have enacted special provisions defining the criminal behavior in sport thus making it a part of their "Sport Legislation". ${ }^{16}$ Great Britain is a specific example in the list of the countries with such legislation as it has enacted a special legislation covering the area of illegal betting.

Despite the fact that the individual European countries are currently under pressure to harmonize and unify their legal orders with the legal rules of the EU, the area of criminal law represents an exception in this case. It is good to point

14 The Black's Legal Dictionary defines the term King's/Queen's evidence so that “if there are more than just one person accused of a crime, one of them testifying against the others based on the promise that he/she will be acquitted, such a person is considered to be providing testimony which is on the same level as the testimony given by the King/Queen or the state." See Black, H.C. et al.: Black's Legal Dictionary. II volume. 6th edition. Prague: Victoria Publishing, 1993, p. 802. Thus it is obvious that the term "cooperating accused" is more appropriate - term which was finally adopted by the Czech legislator.

15 More about cooperating accused - Coufalová, B.: Criminal Justice Rationalization and Its Possibilities when Prosecuting Organized Crime. In: International and Comparative Law Review, 2012.

16 EU Document. 
out that the area of criminal law in the individual European countries retains its own "domestic nature". Although these countries share some common characteristic features the individual criminal codes keep some specifics resulting from historical, cultural and social background of the individual countries. It could be said that the criminal law legal rules are subject to harmonization especially in cases of crimes involving more than just one country (especially different types of economic crime, property crime and organized crime including different types of criminal activities etc.). In these cases the harmonization of law is essential in order to effectively sanction the different types of this criminal activity. The legal regulation (or criminal law legal regulation) covering the area of criminal liability in sport environment is not unified within the European countries.

It is Great Britain which occupies a special position on the list of countries with sport legislation as it has enacted a special legislation covering illegal betting and defining illegal betting as a crime. States falling into the first group are those which have supplemented their Criminal Codes with special provisions sanctioning illegal conduct in the area of sport. Bulgarian criminal law contains a provision under the $\$ 307^{17}$ allowing sanctions for corruptive behavior. Based on this provision it is possible to impose sanctions for match-fixing. This provision is supplemented by $\$ 327$ of the Criminal Code allowing sanctions imposed for the illegal betting in the area of sport. The Spanish Criminal Code contains a similar provision under the $\$ 286$ regulating the area of corruption in sport which in the chapter 4 explicitly lists the persons in the area of sport (players, referees etc.) which can be sanctioned under this provision. All those who illegally manipulate with the progress or results of a specific sporting activity shall be sanctioned under this provision.

Those states whose sport legislation contains provisions criminalizing certain types of wrongful conduct in the area of sport fall into the second group. Cypress and Greece are both countries with special sport legislations. Based on this legislation it is possible to sanction active as well as passive form of corruption. It was Poland which at first adopted a so-called anti-corruption amendment in 2003. This was done as a part of the process of amending the specific criminal law. Subsequently in 2010 a special legislation called Act on Sport ${ }^{18}$ went into effect. This Act contains provisions under which both active as well as passive form of corruption is regarded as a crime. Other types of conduct such as match-fixing and different forms of manipulation with the results and progress of different types of sporting activities are also defined as a crime. States which have adopted special sport-criminal rules fall into the last group. It was Italy which adopted a special legislation regulating the sanctions imposed for corruption in sport as

17 Bulgarian Criminal Code, Art. 307, 327.

18 Act on sport, adopted October 25, 2010 coming into effect October 16, 2010. 
well as illegal betting ${ }^{19}$ in the area of sport, a similar legislation was also adopted e.g. in Malta ${ }^{20}$.

Although it is possible to prosecute cases of illegal activities involving corruption in the area of sport under some general provisions contained in the criminal laws of the individual states, the examples of some foreign legal regulations in some cases prove that this type of conduct can be sanctioned under special sport provisions contained in criminal laws. The other possibility is to adopt special legislation under which certain negative conduct in the area of sport is considered to be a crime. It is possible to state that the countries with such legislation generally regard the corruptive behavior in sport as a serious issue requiring a special legal regulation which should be adopted in order to sanction such a behavior effectively. From this perspective the adoption of a special legal regulation covering this area of conduct in the Czech Republic seems to be a good step as the issue of corruption in the area of sport has proved to be a frequent occurrence in our country.

\section{Conclusion}

Sports environment is connected with many issues which should be regulated by instruments of criminal law. Using of criminal law seems to be necessary in cases when rules of disciplinary bodies are not sufficient. Every social activity must be carried out in accordance with the legal order of the country, the area of sport being no exception.

This article is aimed to specific problems of various forms of corruption or similar acting in sports environment. It is important to deal with this area of civic society because interest of people in sport has been growing and sport has not been already only form of entertainment but it is more and more often connected with great sum of money.

The Czech Republic does not have a special legislation regulating this area. The key legislation regulating this area will thus be represented by the Act N. 40/2009 Coll., of the Criminal Code, as amended. The Criminal Code does not specifically contain the provisions regulating the area of sanctions of illegal and wrongful conduct in sports environment, however, it does contain the provisions regulating the possibility to impose sanctions for frauds, corruption, bribery etc., which will also be applicable in the area of sports environment.

Equally the Czech Criminal Procedure Code contains many institutes which could be used in fighting with the phenomenon of corruption, for example: cooperating accused, wiretapping, using of agent and so on.

19 Law n. 401/1989.

20 Law n. 50/2007.

(C) Palacký University Olomouc, Czech Republic, 2013.

ISSN 1213-8770 (print), ISSN: 2464-6601 (online). 
It is important to notice that since the year 2012 also legal persons has been criminal responsible in the Czech Republic. Act N. 418/2011 Coll regulates criminal responsibility, sanctioning and proceedings of legal persons. This act could be considered necessary for criminal responsibility of sports clubs and similar bodies.

On the other hand many European countries are in the same situation as the Czech Republic. However, there are also some exceptions. For example Italy, Malta, and Portugal have adopted special legislation the aim of which is the sanctioning of wrongful and fraudulent conduct in sport. Bulgaria and Spain have supplemented the existing criminal legislation with specific crimes covering the area of match-fixing and illegal manipulation in the area of sport.

It could be said that there are two possibilities how to solve under the law criminal activities connected with sports environment. The first is to adopt special legislation regulating this area. The second one is to use general legislation.

\section{Bibliography:}

Inquiry Into Betting Clears Davydenko. In: [online]. [cit. 2013-11-06]. Available on: http://www.nytimes.com/2008/09/13/sports/tennis/13tennis.html?_r=0

Daniel Koellerer banned for life for match-fixing. In: [online]. [cit. 2013-11-06]. Available on: http://www.bbc.co.uk/sport/0/tennis/13608639

Tennis player David Savic fails to have life-time ban for match-fixing overturned. [online]. [cit. 2013-11-06]. Available on: http://www.independent.co.uk/ sport/tennis/tennis-player-david-savic-fails-to-have-lifetime-ban-for-matchfixing-overturned-8112851.html

Russian Tennis Player Krotiouk Gets Life Ban for Match-Fixing. [online]. 2013 [cit. 2013-11-06]. Available on: http://www.bloomberg.com/news/2013-0606/russian-tennis-player-krotiouk-gets-life-ban-for-match-fixing.html

Japan: A final takedown for sumo wrestling?. [online]. 2011 [cit. 2013-11-09]. Available on: http://www.globalpost.com/dispatch/japan/110206/sumowrestling-scandal-match-fixing

OLYMPICS; Leaders of Salt Lake Olympic Bid Are Indicted in Bribery Scandal. LONGMAN, Jere. [online]. 2000 [cit. 2013-11-30]. Dostupné z: http://www. nytimes.com/2000/07/21/sports/olympics-leaders-of-salt-lake-olympic-bidare-indicted-in-bribery-scandal.html

World: Asia-Pacific. [online]. 1999 [cit. 2013-11-08]. Dostupné z: http://news. bbc.co.uk/2/hi/asia-pacific/296910.stm

How the 2004 Olympics Triggered Greece's Decline. [online]. [cit. 2013-11-08]. Available on: http://www.businessweek.com/articles/2012-08-02/how-the2004-olympics-triggered-greeces-decline 